\title{
Editorial
}

\section{AQ1-AQ5 Geographies of discontent: sources, manifestations and consequences}

\author{
a Director of Brexit Studies, University of Birmingham, UK, Alex.DeRuyter@bcu.ac.uk \\ ${ }^{b}$ Department of Geography, University of Cambridge, UK, rlm1@cam.ac.uk \\ ${ }^{c}$ Department of Land Economy, University of Cambridge, UK, pt23@cam.ac.uk
}

1.15 Introduction: great disruptions: the new normal?

Recent history has not been kind to Fukuyama's 'end of history' thesis, expounded thirty years

1.20 ago (Fukuyama, 1989, 1992). Writing back then, with the fall of the Berlin Wall, and the break-up of the Soviet Union, Fukuyama's contention concerned what he saw as the triumph of Western-style liberal-democratic free-market 1.25 capitalism. Subsequent events have thrown such celebratory claims of the success of global political and economic liberalism into question. The resurgence of Russia, the ascendancy of China's state authoritarianism, and the rise 1.30 of Islamic fundamentalism are all proof that major ideological contests have far from disappeared. Yet further, over the past two decades or so, disruptions and upheavals within and among the capitalist West itself have revealed 1.35 the fragility of market-based democracies.

The verities of the post-war social democratic model that underpinned Western capitalism - albeit to varying degrees and in various guises across countries - namely a commitment

1.40 to full employment, rising real incomes, social inclusion and equal access to public services, including health care, have increasingly unravelled. The Western social order no longer fulfils its promise of an economy that offers 1.45 a good place for everyone. As Sandbu (2020) 1.46 puts it: 'just as an economy used to sustain a psychological, sociological, and political togetherness, so the end of economic belonging has undermined these types of cohesion' (9). Large numbers of people in the West who could previously expect decent earning 2 cure jobs are instead now confronted wi recarious employment that often pays too little to maintain a reasonable standard of living. It has also become clear that this predicament particularly affects not only certain social groups but also certain places and regions, with detrimental impacts on the communities involved. At the same time, other groups and places have enjoyed rising prosperity and richer opportunities than ever before.

It is not surprising that those groups and places excluded from these gains, benefits and advantages feel aggrieved. They see the economy and the rules that govern it as having been rigged for the benefit of others, especially the political, corporate and financial elites that set the rules and who are based in the most prosperous places. Again, to quote Sandbu, 'an economy-and politics - that benefits some people and places while locking others out of prosperity is what the end of belonging means' (10). Even Fukuyama now recognises this problem. Writing in 2014, on the 25th anniversary of his original essay on the end of history, he acknowledged that the biggest problem for the democratically elected governments 
in some countries was not ideological but 'their failure to provide the substance of what people want from government: personal security, shared economic growth and the basic

2.5 public services...that are needed to achieve individual opportunity'. (https://www.wsj.com/ articles/at-the-end-of-history-still-standsdemocracy-1402080661). Across many Western countries, the failure of the post-war liberal

2.10 democratic political-economic model to provide those expected outcomes for many groups and places has resulted in disillusionment and disaffection - in 'geographies of discontent'.

As such, we would argue that the current 2.15 period offers a particularly critical juncture in this regard, whereby the disruptions brought about by increasing automation, inequality and uneven development, climate change and most recently the Covid-19 pandemic, and their

2.20 manifestly unequal spatial impacts, point to a series of possible and uncertain futures. In the material that follows, we offer an overview of the 'geographies of discontent' and highlight the possible role of the State, before introducing 2.25 the contributors to this issue of the Cambridge Journal of Regions, Economy and Society.

\section{Sources of discontent}

2.30 In seeking to assess the sources of discontent, a wide range of socio-economic and environmental factors come into play. Indeed, throughout history, the impact of the disease has often been pivotal in driving disruptions

2.35 that can up-end entire civilisations, as the spread of smallpox during the European conquest of the Americas demonstrated; which devastated Native American populations (Diamond, 2013), ${ }^{1}$ or the impact of the 'Black Death' in the 2.40 14th century in shifting the balance of power in feudal societies (as the 1381 Peasants' Revolt in England would attest). Major economic dislocations and disruptions have likewise driven social discontent, such as the Luddite textile 2.45 workers' protest at technological change in 2.46 the early 19 th century. That these sources of discontent have always had marked spatial aspects is also evident (AIRoy, 1970). The discussions on 19th-century populism in the USA (Taggart, 1948) and the then Russian Empire (Fedotov, 1942), for example, were framed in terms of agricultural communities.

As such, geography (and therefore territory) has been significant simply by dint of the fact that areas, or regions, that are marginal in physical, economic or political terms (or a combination thereof) are more prone to discontent, as the current literature on 'left behind places' (for example, Rodriguez-Pose, 2018) would attest. That is, what is integral here is the sense (in economic or political terms) of the level of connection to the spatial concentration of knowledge and power in societies (Gregory, 2015). Echoing contemporary developments, rural areas were more resistant to the spread of new ideas emanating from urban centres. For example, the spread of Protestantism in Northern Europe was often accompanied by rebellion and violent insurrection in more remote, conservative areas far from the seats of power-for example, the 'Pilgrimage of Grace' in Yorkshire in 1536, where a combination of economic, political and ecclesiastical factors underpinned the revolt against Henry VIII (Davies, 1968).

However, the link between discontent and economic hardship is complex. It is certainly true that the inter-war years of the 20th century saw both economic misery - whether from hyperinflation or depression-and the emergence of a wide variety of political parties which departed from conventional orthodoxy. While attention is naturally drawn to the NSDAP and the rise of Hitler, and the war and genocide they eventually prosecuted, the 1930s saw a wholesale move away from the laissez-faire economics that had previously been politically mainstream - whether towards the New Deal economic policies of Franklin D Roosevelt or Oswald Mosley's British Union of Fascists. It is notable that many of the areas that have in present times redrawn the political map exhibited considerable discontent during this period 
as well. Jarrow in North-East England is a typical example: famous for the Jarrow March of 1936, it also probably voted overwhelmingly to leave the EU in 2016 (Hanretty, 2016). The 3.5 salience of the link between two such pivotal events 80 years apart has been noted elsewhere (Allen, 2021).

Yet economic hardship alone can hardly be seen as the only driving force behind the dis3.10 content of the 1920s and 1930s and the dramatic events this engendered. After all, by the standards of most of human history and most of the world at the time, Europeans (and even more so a majority of Americans) of the 1930s enjoyed 3.15 enviable living standards, especially when compared to the subjugated colonial populations across Africa and Asia, for whom discontent against European rule would erupt in the independence movements of the 1940s and 1950s.

3.20 One could make the point that these peoples were the ultimate example of communities far removed from the social-spatial concentrations of power: populism has hardly been limited to wealthy nations. In the post-war period, Egypt's

3.25 Nasser could very reasonably be labelled a populist leader. ${ }^{2}$ Similarly, Narendra Modi is not the first Indian leader to be associated with the label (Subramanian, 2007).

Yet for all that, recent events have led to a 3.30 flurry of scholarly activity and new research in the field. However, populism and discontent both have a long history of academic study. Indeed, much was already apparent from Ionescu and Gellner's pioneering study 3.35 of the subject in the late-1960s. Even at that time, the particular spatial manifestations of populist movements were noted, being in areas or countries 'peripheral to economic power' (AlRoy, 1970, 969), alongside the

3.40 'tensions' associated with spatial disparities in economic development (and particularly within-country disparities). Populism as both a discursive concept and as an ideology, though, has shifted through the years3.45 proving remarkably difficult to pin down 3.46 (Gidron and Bonikowski, 2013).
There are, of course, myriad contemporary disruptions that act as sources of discontent, many of which have been operative for some time: globalisation, inequality, and technological and environmental change. Some of the literature of the late 20th century - well before the events of the 'Great Recession'-appears remarkably prescient, foreshadowing recent events (Taggart, 1995, 1997). The risks of majoritarian tyranny, which is arguably inherent to populism, were clearly identified in the American populist tradition (Kazin, 1998). Of course, the period since the 1990s has seen the rapid (re)emergence of China as a pre-eminent economy and the expansion and closer integration of the EU, which sit alongside the USA as members of the 'Global Triad' (Dicken, 2014) within which world economic activity is concentrated. Yet development within these world regions has been increasingly uneven, both spatially and in terms of inter-personal inequality (Dicken, 2014).

Thus in seeking to understand the driving economic factors of contemporary discontent, it is imperative to understand how uneven development and dissociation from the spatial concentrations of knowledge and power has fuelled populist sentiments in particular regions. In this context, the erosion of relative economic privilege has been one of several key factors driving the growth and resurgence of identity politics in recent years. Donald Trump's promise in 2016 to bring back manufacturing jobs had resonance precisely for those groups that have seen the most rapid erosion of their perceived privilege: structural economic change and changes in migration patterns are highly salient factors fuelling discontent.

The problems provoked by the pressure of relatively rapid population change over a short period of time on public service provision can be illustrated by the example of Boston in Lincolnshire (UK) whose population expanded more between 2003 and 2007 than it did between 1981 and 2003. ${ }^{3}$ This was in large part due to the accession of new EU 
member states in 2004, from which large numbers of individuals were drawn to work in the horticultural sector in and around the Boston region. Official statistics suggest that 4.5 the 'white, non-UK national' population expanded from 2500 (4.3\% of the population) in 2004 to 19,900 (29.4\% of the population) in 2017 , before shrinking to $14,200(20.9 \%$ of the population) in 2019. ${ }^{4}$ That growth, in 4.10 turn, put pressure on public service delivery in the region, with Lincolnshire East Clinical Commissioning Group (CCG) (which contains Boston, Skegness and East Lindsay) having 2026 patients per full-time GP in 2019, 4.15 compared to the England average of 1721 patients per full-time GP. The skew is even more extreme when the age of the population is taken into consideration. ${ }^{5}$ It is perhaps not surprising then that such disparities in ser-

4.20 vice provision under the impact of austerity have been argued by some to be key factors in the Brexit vote (Fetzer, 2019; Gietel-Basten, 2016). The Boston parliamentary constituency had the highest 'Leave' share of the vote in the

4.25 UK (some 75\%; see also Hanratty, 2016).

The growing political divergence between many urban areas and their peri-urban hinterlands and the consequent 'revolt of the regions' (MacLeod and Jones, 2018) or

4.30 'revenge of the places that don't matter' (Rodriguez-Pose, 2018) is by no means confined to the UK. Not dissimilar spatial differences in economic, cultural and political conditions can be observed between the

4.35 Ile-de-France and the rest of metropolitan France, between northern and southern Italy, between Istanbul and much of Anatolia. The erosion of 'good work' during the neoliberal post-1980 period (De Ruyter and Burgess,

4.40 2003) and more recent growth of the 'Gig Economy' (De Ruyter and Brown, 2019) is likewise a part of this economic polarisation, although the relationship between this and political outcomes, like the interaction 4.45 between inter-personal and inter-spatial in4.46 equalities, is more complex.
However, economic factors such as stagnant living standards and rapid change are only one facet of many explanations for the manifestations of global discontent. Just as Anderson (1983) regarded the printing press as a catalyst for the emergence of nationalism, so we would argue that the technological changes that have driven the emergence of modern media have become a crucial tool to channel discontent. Certain populist movements appear to have been encouraged often by the widespread dissemination of misinformation or, indeed, absolute untruths, something that has been empowered through the use of social media.

As depicted in the writings of Wired magazine and labelled as 'techno-positivist' by Bridges (2017, p 5), the Internet has been seen as 'a democratising media which has lowered the barriers to entry held by previous gatekeepers and revolutionised personal freedom' But rather than necessarily being a means to more widely distil objective, evidence-based information, the Internet has at times acted as a platform to amplify existing prejudices and peddle highly spurious or false hypotheses (for example, the 'Q-Anon' conspiracy in the USA). And in the current Covid-19 pandemic, it has also enabled anti-vaccination campaigners to spread their dubious views. This provides a marked contrast to the notion that technological change has been unambiguously liberating and empowering in the creation of the networked knowledge economy (Shapiro and Varian, 1999). While these groups are on the fringe, the liberating power of the Internet has given them new reach, and as research into the activities of the far Right has shown, highly distasteful ideas around race and class can be disseminated by such groups to legitimise their way into more supposedly mainstream conversations (Jakubowicz et al., 2017; Klein, 2012). Many of these groups ostensibly see themselves as battling an overweening statewitness the 'denigration of the mainstream media', often from those who themselves maintain significant power and influence via media 
platforms. Indeed, as George Monbiot, writing in the Guardian pointed out:

micro-targeting on social media, peer-to-peer 5.5 texting and now the possibility of deep-fake videos allow today's politicians to confuse and misdirect people, to bombard us with lies and conspiracy theories, to destroy trust and create alternative realities more quickly and

5.10 effectively than any tools 20 th-century dictators had at their disposal. ${ }^{6}$

This leads to an important point; that while disruptions can create the potential for discontent,

5.15 they require agency in order to effect an impact on the status quo. In this regard, the role of the media, and adept communicators who can tap into undercurrents of public opinion (and resentments) has been critical.

\section{Giving voice to discontent}

A useful way-though we stress it is only one way-of conceptualising the differing 5.25 expressions of an individuals' discontent with their local economic, social, political or other circumstances and conditions is in terms of Hirschman's (1970) famous 'ExitVoice-Loyalty' model. In his original model, 5.30 Hirschman posited these three main ways in which individuals (for example, as consumers, workers, or voters) can express their dissatisfaction with events or their circumstances, in particular with a decline in firms, organisations 5.35 and states. Both Exit and Voice are 'active' responses. Exit refers to any attempt or action undertaken by individuals in order to escape a dissatisfying situation, such as ceasing to buy a given product, quitting their job, or abandoning

5.40 their customary support for a particular political party. Contrary to Exit, Voice refers to attempts to change a dissatisfying situation, rather than escaping from it. Voice can be a destructive or constructive response. It can vary 5.45 from explicit protest and disruptive action, to 5.46 dialogic encounters aimed at discussing and suggesting change and solutions. Loyalty reflects passive responses involving continuing support and patience in the hope that the situation or conditions will improve. Fox (2012) gives the following example to illustrate Exit, Voice and Loyalty:

You're a Republican intellectual ... dismayed by the direction your party has taken over past few years. Do you a) switch over to the Democrats [Exit], b) raise hell in the media [Voice], or c) try to stay welcome in the party's corridors of power in order to quietly exercise your influence [Loyalty] ${ }^{7}$

Since first appearing, Hirschman's basic model has been applied to various social, organisational and political examples, and has itself undergone criticism, reappraisal and indeed revisions and elaborations, such as the addition of a fourth response of Neglect, namely passive responses that do not allow conditions to improve, such as absenteeism, reduced work effort, reduced interest, not bothering to vote, and the like. It is now commonly referred to as the EVLN model or typology. Further, it has been argued that these four forms of response to adverse or dissatisfying circumstances may not themselves be distinct (although to combine all four simultaneously would be difficult), and that each may end up having a result opposite to that intended (or hoped for).

Although economists have not, in general, used Hirschman's model, they do invoke exit as a common (and rational) form of economic behaviour, as when a worker quits his/her job out of dissatisfaction with or dispute over, say, pay, to work for another, better paying, employer. They also commonly emphasise how workers will leave (exit) one location, where say job opportunities or pay are poor and prospects are minimal, to move to another location that is more economically buoyant, where job opportunities are more numerous and wages are higher. Exit, that is outward migration, then becomes one way in which discontent with the 
conditions and opportunities in economical lagging localities and places finds expression among the individuals and social groups affected. We know that economically depressed 6.5 and lagging areas do tend to be areas of net outward migration. But whether and how far this leads to a subsequent improvement in the economic problems in lagging or 'left behind places' (for example, by reducing local 6.10 labour supply and hence forcing local employers to pay better wages) is questionable. Such geographical exit behaviour tends to be selective, in that it is the more educated, more enterprising and younger members of the local 6.15 workforce who are more likely to abandon a lagging area for another more economically dynamic area elsewhere. This 'spatial selection', as urban economists like to call it, may therefore simply leave the least educated or skilled

6.20 workers trapped in their depressed locality. Also, social and community ties, and housing market conditions, may also limit Exit behaviour (out-migration). Exit may not, therefore, serve to reduce regional inequalities in the

6.25 'self-correcting' way beloved by neoclassical economists.

In such circumstances, it is hardly surprising where such inequalities persist over an extended period of time that Hirschman-style Voice be6.30 comes the form of active response in the lagging areas. Discontent among the local populations of such areas, who are unable or unwilling to move out, may reach a point where different forms of open protest and disaffection surface.

6.35 The series of hunger marches from the economically depressed, high unemployment coalfield and heavy industry areas of northern and midlands Britain down to London in the 1920s and 1930s are a classic example of geographical 6.40 Voice behaviour. The UK coalminers' strike by the country's pit communities in 1984-1985 is another. The Brexit vote of 2016, in which some of the highest proportions of local populations voting to leave the European union were in 'left 6.45 behind' constituencies, is yet another. In this ex6.46 ample, Voice acted to secure Exit (cessation of membership of the EU). A more recent example illustrates how Exit behaviour may function as a form of Voice. In the UK 2019 General Election the electorates in many northern constituencies-so-called 'Red Wall' constituencies, areas that had traditionally been staunch Labour heartland areas-abandoned Labour in large numbers and voted instead for the Conservative Party. Seemingly disillusioned with the failure of Labour to tackle the longstanding economic disadvantages of their areas, they switched their allegiance to Boris Johnson with his promise 'to get Brexit done' and 'level up' the country. Similarly, Trump's presidential success in 2016 also reflected, in part, the disillusionment of the residents of rundown and left behind towns and cities in the USA's Rust Belt states, areas that more typically had been Democrat but which abandoned the latter in favour of the Republicans, again influenced by Trump's promise to 'bring jobs back to the USA'.

Clearly, these and other examples of discontent in economically depressed localities cannot be wholly or solely explained in terms of Hirschman's schema. But the latter nevertheless offers an interesting framework for further work and analysis. When Hirschman first proposed his framework, there were no social media platforms of the sort that exist today. These platforms can be used to spread discontent, and to mobilise collective Exit and Voice behaviours. This was a crucial dimension of the Brexit, Johnson and Trump votes. A relevant question is whether, to what extent, and under what circumstances, social media increase the attractiveness and effectiveness of Voice relative to Exit,.

\section{The geographical manifestations of discontent: contributions in this special issue}

Against this background, this Special Issue examines a number of the key issues that have been argued to shape the geography of discontent and, importantly, how societies might respond to the 
challenges presented. The emphasis has been on examining evidence from a number of countries using different measures of discontent. As discussed in the previous section, how people express their discontent can vary considerably from formal voting channels to more informal channels like social media to direct social action, such as public marches and protests.

A key theme in much of the research is to as7.10 sess the relative importance of spatial economic inequality as a driver of social discontent and its subsequent political expression. Moreover, it is of great interest to establish whether views are influenced more by perceptions rather than 7.15 more evidenced based indicators. Diaz-Lanchas et al. (2021) recognise that the causes of recent expressions of social discontent across the regions of the EU are complex and to understand them properly it is necessary to bring together 7.20 the contribution of both contextual factors and personal attitudes. Their hypothesis is that discontent is the result of how individuals perceive both their present and future well-being which is, to some degree, informed by the eco7.25 nomic conditions they are experiencing. Their measure of discontent is dissatisfaction with the EU, based on a composite indicator of responses from the Eurobarometer Surveys in 2018 and 2019. This is combined with regional 7.30 contextual data to control for the conditions faced by individuals in particular locations.

Their findings confirm the importance of economic factors on individual discontent, particularly among those who consider they have 7.35 been 'losers' from globalisation, who tend to be relatively less well placed in the labour market and live in the lagging regions. While they recognise that these findings are relatively well known, their analysis suggests that these effects 7.40 are compounded by how individuals shape future expectations. They also find that attitudes to the EU are primarily affected by how individuals perceive their national democratic system. The authors consider that there are im7.45 portant implications for how EU and national 7.46 policies should respond to the negative spatial impacts that arise from the Covid-19 pandemic and other such future challenges.

In a similar vein, Segovia et al. (2021) examine the links between social discontent and inequality in Latin America. They consider three types of factors that might be associated with dissatisfaction with democracy. These are personal characteristics, inequality related variables and measures of institutional quality. They use data from the latest Lationbarometro (2018) Opinion Survey that provides evidence on 18 Latin American countries and Spain. They argue that their results confirm previous research on explanations of social discontent in Latin America. It does seem as though inequality of opportunity and poor institutional quality are associated with discontent and that traditional measures based on the Gini Index may be less appropriate. They find that personal characteristics other than socioeconomic status are less significant.

In the Spanish context, Arana (2021) assesses the economic and social factors behind the rise in support for the Spanish right wing party Vox and for Catalonian independence. She examines the impact of the substantial rise in unemployment in Spain following the financial crisis and subsequent austerity measures which reinforced the substantial degree of regional inequality across Spain. Her conclusion is that the impact of regional economic inequality has to be considered alongside the political issues facing Spain since the return to democracy in 1977 and the formation of the first coalition government.

Rodriguez-Pose et al. (2021) argue that the rise in social discontent that arguably underpinned the election of Donald Trump in 2016 was not the result of widening interpersonal income (and wealth) inequality in American society, nor a reflection of the ability of social capital or traditional forms of civic engagement to help in containing resentment. Rather, the explanation lies in the impact across regions in America of longer term economic and population decline. In fact, interestingly, those areas 
that supported Trump the most were likely to be characterised by relatively high levels of social community and did not thus fall easily into areas 'bowling alone' as described in Robert

8.5 Putman's seminal work. They chose to 'golf' with Trump to express their dissatisfaction and, if anything, high levels of social capital reinforced their collective ability to speak-out.

Denti and Faggian (2021) provide another

8.10 interesting analysis of how discontent with economic circumstances can manifest itself in ways other than the ballot box. Their research, based on data for Italy, examines whether spatial income inequality is associated with spatial

8.15 variations in the incidence of cyberhate crime. Their findings support the view that income inequality does indeed foster a higher incidence of cyberhate even after allowing for other factors like unemployment and immigration.

8.20 Worryingly, they find that the impact is not attenuated by areas having higher levels of educated people - and in fact, the opposite.

Whatever the precise importance of individual factors in the generation of social dis-

8.25 content, there is evidence that people also react to how well they perceive their needs are being addressed by local and central government and thus issues of governance and policy. Drawing on evidence on the spatial nature of the UK

8.30 Brexit vote De Ruyter et al. (2021) show that regional governance arrangements play a key role. Combining data on Brexit voting patterns in the West Midlands and Scotland with evidence from targeted interviews and

8.35 focus groups, they have gained insight into why people voted the way they did. After allowing for demographic factors, their analysis shows that perceptions of how well regional governance arrangements were responding to

8.40 their needs was of importance. In this respect, the fragmented sub-national governance position in England in recent years relative to Scotland was an important influence on differences in voters' perceptions between these 8.45 regions. There is a clear message here, and it is 8.46 that local governance arrangements and how voters perceive that local (and central) government are responding to the economic challenges they face, matter. The implications for the current British 'Levelling-up' agenda are obvious.

This view is reinforced in the research provided by Weller (2021) who analyses voting patterns in two disadvantaged and deindustrialising areas in the State of Victoria, Australia. She considers the extent to which a federal political system, a preferential voting system and timely policy intervention can help to mitigate social discontent and its expression infringe or protest voting. Her analysis is persuasive and she concludes that debate in Europe on voter rebellion takes insufficient account of the overall democratic representation process, and how governments respond to places facing economic turmoil. She suggests that 'explanations for the rise of populism in Europe could spend more time asking why political frameworks have not responded in a more timely way to localised crisis, and why they have not sufficiently acknowledged that places and the people in them do matter'.

The research presented by McCann and Ortega-Argiles (2021) picks up on the inadequacy of the traditional policy response to the geographical imbalances created by deindustrialisation, the financial crisis and other factors that have created such spatial asymmetry of British prosperity. Core to their argument is that the assessment by Government, and indeed wider British society, as to the nature of the problem of regional imbalance problem, and how best to respond to it, is heavily influenced by popular narratives that often gain acceptance and currency but with Coak evidential credentials. They use the xample of the Brexit vote to good effect in this respect and also recent discussion on 'Levelling-Up'. These narratives are not always 'heavily anchored in economic realities' and their distillation into policy responses hinder attempts to 'genuinely rebalance or level up the economic geography of place'. 
There is much interest in understanding whether there are systematic differences between urban and rural areas in political discontent and the key influences involved. 9.5 Recognising that the existing research base is relatively thin, Kenny and Luca (2021) analyze pooled, cross-sectional individual-level data from the European Social Survey over the period 2002-2018 for the EU27 Member States, 9.10 the United Kingdom, Norway and Switzerland. They find that there does appear to be powerful and significant differences in social and political attitudes, but they do not reflect a simple binary urban and rural division but rather a

9.15 gradient from inner cities to suburban towns and rural areas. Differences are due to compositional and contextual factors. Understanding these is clearly important in developing policy responses.

9.20 Yet another take on the urban-rural dimension is provided by Larsson et al. (2021) who support the Kenny and Luca finding that it is not appropriate to adopt a rigid urban-rural, core-periphery or even North-South dichotomy

9.25 in understanding the geography of discontent. They argue for a more nuanced approach that reflects how a place relates to its surrounding communities and regions. Thus, 'relational proximity' is important in understanding the

9.30 geography of discontent. They analyze the municipal distribution of electorate support for Swedish Democrats in the 2014 and 2018 national general elections. Interestingly, their accessibility measures are based on wages dis-

9.35 counted by time-travel distances. Their findings suggest that greater accessibility to other large municipalities within the same region appears to have influenced support for the Swedish Democrats. Whether an area is surrounded by 9.40 relatively larger neighbouring municipalities has also been important. Clearly, why and how proximity effects influence relative discontent, and its political expression, should be the subject of future research.

9.45 A further important issue in this respect re9.46 lates to whether individuals consider that their capital city has a positive or negative influence on the development of their own region and how this affects their levels of trust, their sense of being Left Behind and their degree of relative inclusivity in the national economic development. Rickardsson et al. (2001) use recent panel survey data for Sweden to investigate how individuals in different regions perceive the impact of their capital city of Stockholm on development of their own region and also Sweden taken as a whole. They find that individuals who perceive that the development of their own region has been 'less advantageous' tend to consider the capital has had a negative effect on the area they live in and the country taken as a whole. This view tends to increase with degree of peripherality.

\section{Concluding reflections}

This Special Edition concludes with brief commentaries from three scholars who have much long-standing experience in studying regional and urban economic development. Florida (2021) believes that rising discontent has to be seen as a "quintessentially geographic phenomenon - a fundamental product of distinctive economic and cultural geographies and of deepening differences in the day-to-day lives of different class and racial groups'. He considers the rise of discontent on the political right in the USA and elsewhere to emphasise the importance of conservative values among voters and their dissatisfaction with the politics and political culture of post-industrial society. So much so that in some cases people do not necessarily vote to reflect what is best for their own economic interest. In this respect he reinforces the findings of Rodrequez-Pose, Lee and Lipp (2021) that many voters voting for Donald Trump were not necessarily rebelling against relative decline in their incomes or feeling isolated due to a decline in the social capital in their local communities. In fact, to the contrary, Florida builds on the importance of cultural factors in the expression of discontent 
emphasising the role of psychological and emotional factors. However, he also argues that it is necessary to recognise the role of spatial sorting whereby people with particular values

10.5 group with others of the same disposition in particular places. And, in this respect, a key example has been the move of those with 'more open-minded, liberal or cosmopolitan values moving to bigger cities and tech-hubs, while

10.10 those with less education and less skill and who hold traditional family values are concentrated in left behind places and in suburbs and rural areas'.

He suggests that such spatial sorting associ10.15 ated with structural shifts in societies from industrial to tertiary knowledge based structures shows how the geography of discontent evolves and changes through time with changes in the nature of capitalism and the impact of tech-

10.20 nology on the nature of work. He emphasises the tendency for the rise of a 'spiky, increasingly winner take all geography' with a relatively small number of places and the people in them doing very well fueling discontent among 10.25 those in less well-off places and circumstances. He sees this as the key 'fault-line' in the political divide. However, as he points out, even the largest superstar cities have powerful divisions within them that can fuel discontent. Florida 10.30 emphasises that it is unwise to see social discontent and its geographical dimensions as in anyway a static phenomenon, but rather a fundamental feature of the way in which capitalist societies churn.

10.35 Oliveira Martins (2021) argues that although economic change in society usefully results in increased income and employment in aggregate there are often substantial geographical differences in the winners and losers

10.40 from the process. As he argues, this emphasises the need for policy intervention to compensate the losers. Otherwise, as the research in this Special Edition shows, there is often increased social discontent. However, as is now 10.45 widely realised, 'place-based' policy interven10.46 tions aimed at improving economic and social conditions in 'left behind' places have to be sensitive to what works and why. As he argues, by tailoring policies to places, national policy makers can optimise their possibility of generating productivity enhancing employment growth. However, this often requires attention to ensuring the appropriate policies are adopted and that adequate sub-national governance structures are in place. He points to the attention that the OECD has given to encouraging 'Effective Public Investment across Levels of Government ${ }^{8}$ ". Such effective subnational intervention has become of even greater importance in the light of the differentiated spatial impacts of the Covid-19 crisis. He suggests that the advances made in digital technology, together with new opportunities for where people will actually work, has changed the 'spatial equilibrium' of employment opportunities in ways that may well mitigate some of the social discontent that has emerged from previous waves of economic change. In a similar fashion there are opportunities for new spatial divisions of labour as governments react to climate change.

Muro (2021) focuses on how the 2016 and 2020 American elections have emphasised the pronounced economic disparities that have emerged in America between what he sees to be the diverse and mainly thriving metropolitan regions and the small towns, ex-urban and mainly rural areas. Regional divergence in economic opportunities has generated social discontent that has found expression in the ballot box. He believes that many Americans are now of the view that neither market forces or the rise of technology clusters are going to do much for them. In fact, many Americans look with increasing nervousness at a geographical divide that contains 'a short list of 'superstar city' regions and a long list of places going sidewise or being 'left behind'.

A particularly telling statistic is that the five 'superstar' metro areas of Boston, the San Francisco Bay Area (San Francisco and San
10.50 
Jose), Seattle, and San Diego created $90 \%$ of all innovation sector job growth between 2005 and 2017. By way of contrast, some 224 out of 382 US metro areas saw their share of the na11.5 tional innovation decline over the period. In short, the American geography of innovation has been one of 'winner-takes-most'. The dramatic concentration of economic power in relatively few regions is now challenging the 11.10 belief held by successive American administrations that market forces will eventually bring about regional convergence. The new Biden administration is unleashing a wave of place sensitive programmes centred on pro11.15 curement, R\&D policy, infrastructure, training and education.

However, concerns still remain about both the relative commitment and eventual effectiveness of the mainstream response. Some re11.20 assurance on commitment is provided by the sheer scale of the Biden Build Back Better reconstruction agenda, which could amount to some $\$ 7$ trillion. As part of this, there are plans to create 18 regional 'technology hubs', 11.25 and encouragingly these proposals appear to carry bipartisan legislative support. It is recognised that generous funding will be required. However, Munro suggests that technology hubs aside, there is a need for a more radical approach to how the economic problems of relatively 'left behind' regions in America are addressed. Funding is needed to tackle the 'place conscious' needs of lagging regions across a range of issues, including infrastruc11.35 ture, labour market development and much more besides. And there are worrying questions that remain as to what should be the appropriate geographical scale of assistance, and thus whether Federal support will end up being 11.40 spread too thinly and thus incapable of having enough economic impact to quell the social discontent in 'left behind' places. However, as Munro concludes, it is encouraging that the problems of economically lagging places are 11.45 now firmly on the agenda of the current USA 11.46 administration.

\section{Endnotes}

${ }^{1}$ It has been estimated that disease unknowingly introduced by Europeans accounted for $95 \%$ of Native American casualties in North and South America during the post-Columbian period. Smallpox was responsible for the deaths of some $50 \%$ of the Incas during the first epidemics. See https://www.nationalgeographic.com/science/article/ news-guns-germs-steel-jared-diamond-interview.

${ }^{2}$ Of course, a rather orientalist (Said, 1978) lexicon, Nasser's mass appeal was given the-typically derogatory-label of the 'Arab street' (Regier and Khalidi, 2009).

${ }^{3}$ https://www.nomisweb.co.uk/query/construct/summary.asp mode $=$ construct $\&$ version $=0 \&$ dataset $=31$.

${ }^{4}$ https://www.nomisweb.co.uk/query/construct/summary.asp? mode $=$ construct $\&$ version $=0 \&$ dataset $=17$.

${ }^{5}$ https://files.digital.nhs.uk/36/AECDCB/GPW\%20 Detailed\%20Tables \%20September \%202019\%20 -\%20NHSE.xlsx Available from: https://digital. nhs.uk/data-and-information/publications/statistical/general-and-personal-medical-services/ final-30-september-2019.

${ }^{6} \mathrm{https}: / /$ www.theguardian.com/commentisfree/2020/ jul/02/donald-trump-boris-johnson-fascism-us-ukrightwing.

${ }^{7}$ https://hbr.org/2012/12/exit-voice-and-albert-ohirsch.html.

${ }^{8} \mathrm{xxx}$.

\section{References}

Allen, V. (2021) Retracing, remembering, reckoning: Stuart Maconie's footsteps narrative of the Jarrow March. In D. Keller and I. Habermann (eds.), Brexit and Beyond: Nation and Identity. Tübingen: Narr Franke.

AlRoy, G. C. (1970) Populism: its meaning and national characteristics. Edited by Ghita Ionescu and Ernest Gellner. (1969. pp. 263. New York: Macmillan. \$6.95.), American Political Science Review, 64: 968-969.

Anderson, B. (1983) Imagined Communities: Reflections on the Origin and Spread of Nationalism. London: Verso.

Arana, A. G. (2021) Politics of discontent in Spain; the case of Vox and the Catalonian independence movement, Cambridge Journal of Regions, Economics and Society. 
Bridges (2017)

Davies, C. (1968) The Pilgrimage of Grace reconsidered, Past and Present, 41: 54-76.

Denti, D and Faggian, A. (2021) Where do angry birds tweet? Economic inequality and cyberhate in Italy, Cambridge Journal of Regions, Economy and Society.

De Ruyter, A. and Brown, M. (2019) The Gig Economy: Old Wine in a New Label? NewcastleUpon-Tyne: Agenda.

De Ruyter, A. and Burgess, J. (2003) Growing labour insecurity in Australia and the UK in the midst of jobs growth: beware the Anglo-Saxon Model!, European Journal of Industrial Relations, 9: 223-243.

De Ruyter, A, Hearne, D, Mansoob Murshed, S, Rowe, J and Whittam, G. (2021) Understanding changing voter perceptions and attitudes towards Populism: Brexit evidence from Scotland and the West Midlands, Cambridge Journal of Regions, Economy and Society.

Díaz-Lanchas, J, Di Pietro, P and Sojka, A. (2021) Menaced, miserable or misunderstood? The interplay of individual perceptions and negative economic conditions in shaping discontent across the European Union regions, Cambridge Journal of Regions, Economy and Society.

Dicken, P. (2014) Global Shift. Mapping the Changing Contours of the World Economy, 7 th ed. Sage Publishing.

Fedotov, G. P. (1942) The Russian Review, 1

Fetzer, T. (2019) Did austerity cause Brexit?, American Economic Review, 109: 3849-3886.

Florida, R. (2021) Discontent and its geographies, Cambridge Journal of Regions, Economy and Society.

Fox, J. (2012) Exit, voice and Albert O. Hirschman, Harward Business Review.

Fukuyama, F. (1989) The End of History?, The National Interest, 16: 3-18.

Fukuyama, F. (1992) The End of History and The Last Man. New York; Toronto: Free Press; Maxwell Macmillan Canada.

Gidron, N. and Bonikowski, B. (2013) Varieties of Populism: Literature Review and Research Agenda. Working Paper Series, Weatherhead Center for International Affairs, Harvard University.

12.40 Gietel-Basten. S. (2016) Why Brexit? The toxic mix of immigration and austerity, Population and Development Review.

Gregory, A. (2015) Innovative teaching in situational awareness, Clinical Teacher, 12: 331-335.

Hanretty, C. (2016) Revised estimates of Leave vote share in Westminster constituencies. Available online at: https://medium.com/@chrishanretty/ revised-estimates-of-leave-vote-share-inwestminster-constituencies-c4612f06319d.

Hirschman, A. O. (1993): Exit, voice, and the fate of the German Democratic Republic: an essay in conceptual history, World Politics, 45: 173-202.

Jakubowicz, A., Dunn, K., Mason, G., Paradies, Y., Bliuc, A. M., Bahfen, N., Oboler, A., Atie, R. and Connelly, K. (2017) Cyber Racism and Community Resilience: Strategies for Combating Online Race Hate. Palgrave Macmillan.

Kazin, M. (1998) Democracy betrayed and redeemed: Populist traditions in the United States, Constellations, 5: 75-84.

Kenny, M. and Luca, D. (2021) The urban-rural polarisation of political disenchantment: an investigation of social and political attitudes in 30 European countries, Cambridge Journal of Regions, Economic and Society,

Klein, A. (2012) Slipping racism into the mainstream: a theory of information laundering, Communication Theory, 22: 427-448.

Larsson, J, Oner, O and Sielker, F. (2021) Regional hierarchies of discontent an accessibility approach, Cambridge Journal of Regions, Economic and Society,

Los, B., McCann, P., Springford, J. and Thissen, M. (2017) The mismatch between local voting and the local economic consequences of Brexit, Regional Studies, 51: 786-799.

Martins, J. O. (2021) Cambridge Journal of Regions, Economic and Society.

McCann, P. and Ortega-Argilés, R. (2021) The geography of discontent: narratives, drivers and evidence-based challenges to policy-making, Cambridge Journal of Regions, Economic and Society.

Monbiot, G. (2020) Trump and Johnson aren't replaying the 1930 but it's just as frightening. The Guardian. Available online at: https://www. theguardian.com/commentisfree/2020/jul/02/ donald-trump-boris-johnson-fascism-us-ukrightwing.

Muro, M. (2021) Recognising the geography of discontent in the U.S: 'building back better' by countering regional divergence. Cambridge Journal of Regions, Economic and Society.

Regier, T. and Khalidi, M. A. (2009) The Arab street: tracking a political metaphor, The Middle East Journal, 63: 11-29.

Rickardsson, J., Mekkander, C. and Bierke, L (2) 1) The Stockholm Syndrome - the view of Sto $1 \mathrm{~m}$ by the 'places left behind', Cambridge Journal of Regions, Economic and Society.

Rodriguez-Pose, A. (2018) The revenge of the places that don't matter (and what to do about
AQ17 
it), Cambridge Journal of Regions Economy and Society, 11: 189-209.

Rodriguez-Pose, A., Lee, N. and Lipp, C. (2021) Bowling with Trump, Cambridge Journal of Regions, Economic and Society.

13.5 Rodrik, D. (2018) Populism and the economics of globalization, Journal of International Business Policy, 1: 12-33.

Said, E. W. (1978) Orientalism. London: Routledge and Kegan Paul.

13.10 Sandbu, M. (2020) The Economics of Belonging. A Radical Plan to Win Back the Left Behind and Achieve Prosperity for All. Princeton University Press.

Segovia, J., Pontarollo, N. and Orellana, M. (2021) Social discontent and inequality in Latin America, Cambridge Journal of Regions, Economic and Society.
Shapiro, C. and Varian, H. R. (1999) Information Rukes: A Strategic Guide to the Network Economy, p. 352. Boston, MA: Harward Business School Press.

Subramanian, N. (2007) Populism in India, SAIS Review, 27: 81-91.

Taggart, H. F. (1948) Thomas Vincent Cator: populist leader of California, California Historical Society Quarterly, 27: 311-318.

Taggart, P. (1995) New populist parties in Western Europe, West European Politics, 18: 34-51.

Taggart, P. (1997) The populist politics of Euroscepticism. Available online at: http://aei.pitt. $\mathrm{edu} / 2740 /$.

Weller, S. (2021) Places that matter: voter responses to Australia's localised crisis intervention framework, Cambridge Journal of Regions, Economic and Society. 